Jan Grosfeld, Stosunek do Żydów i judaizmu jako warunek

drogi do jedności chrześcijan, [w:] o co chodzi w ekumenizmie? Czym jest dialog? Podstawowe idee Vaticanum II pót wieku później, red. Marek Kita, Kraków 2015, s. 131-155.

DOI: http://dx.doi.org/10.15633/9788374384551.09

Jan Grosfeld

\title{
Stosunek do Żydów i judaizmu jako warunek drogi jedności chrześcijan
}

Pragnę postawić tezę, która moim zdaniem ma centralne znaczenie dla chrześcijaństwa. Otóż jestem głęboko przekonany, że odnajdywanie żydowskich korzeni chrześcijaństwa stanowi fundamentalny warunek realizacji jedności różnych wyznań chrześcijańskich. Podział chrześcijan jest skandalem dla świata, gdyż Bóg jest jednością, harmonią, owym hebrajskim shalom, za którym tęskni ludzkie serce. Źródłem podziału są zawsze, jak mówi św. Paweł, „duchowe siły zła”. Jezus Chrystus wymienia dwa znaki rozpoznawcze chrześcijan: miłość i jedność. W tym wyraża on swą żydowskość, czyli nadzieję mesjańską: obecność Boga, Szekina, rozpięła swój namiot na ziemi. Dzięki paschalnemu wydarzeniu Jezusa z Nazaretu do tego namiotu ma wstęp każdy. Przeczuwa to XX-wieczna filozofia dialogu, która relację z innym, z drugim człowiekiem, traktuje jako newralgiczne miejsce, w którym doświadczamy wielkich ograniczeń, barier, podważających sens życia. Sięgać do żydowskiego źródła, z którego rodzi się cała historia zbawienia, oznacza stawiać na nogi to wszystko, co w historii stanęło na głowie. Celem religii jest wiązać ludzi z Bogiem, a tym samym ze sobą na gruncie pewnym, który nie będzie zawodził, nie na ludzkim rozumie, projekcjach i utopiach. Religia chrze- 
ścijańska zakorzeniona w żydowskim gruncie i doświadczeniu nie będzie tak podatna na instrumentalizację, jak to miało i ma miejsce $\mathrm{w}$ historii. Takie chrześcijaństwo przywraca sens osobie, wspólnocie i światu, a dając odpowiedź na sens cierpienia, rodzi wciąż odnawiającą się nadzieję mesjańską i egzystencjalną. Zapewne to również miał na myśli Jan Paweł II, gdy w resztki jerozolimskiej Ściany Zachodniej włożył, na wzór religijnych Żydów, swą własną modlitwę z prośbą o przebaczenie chrześcijanom zła wyrządzonego ludowi Izraela. Podobnie uczynił później Benedykt XVI. Wrażliwość na orędzie Jezusa Chrystusa musi zawierać w sobie wrażliwość na własny grzech poprzez dostrzeganie cierpienia innych. Jako następstwo pojawia się prośba o przebaczenie i wreszcie pojednanie ${ }^{1}$. Tutaj rzecz jasna pojawia się znany dylemat, rodzący wiele kontrowersji, a nawet niechęci: Czy i jak prosić o przebaczenie za zło wyrządzone nie przeze mnie osobiście, lecz przez innych, którzy są lub byli członkami tej samej wspólnoty? W Biblii można znaleźć argumenty zarówno za, jak i przeciw odpowiedzialności za grzechy innych. Jednakże trudno podważyć dar rozeznania duchowego i mądrość obu wspomnianych wyżej papieży, którzy wyznawali skruchę i kierowali prośbę o przebaczenie do wszystkich ofiar ludzi Kościoła, w tym bardzo mocno do Żydów. Podobnie i dokumenty episkopatu Polski wyznający grzechy członków Kościoła trudno katolikom negować ${ }^{2}$.

1 Wyczerpującą i piękną prezentację zagadnienia dotyczącego przebaczenia i pojednania w nauce chrześcijańskiej zawarł ks. P. Mazurkiewicz w tekście Przebaczenie i pojednanie. P. Mazurkiewicz, Przebaczenie i pojednanie, „Chrześcijaństwo-Świat-Polityka. Zeszyty społecznej myśli Kościoła” (2006) 1 (1), s. 7-32.

2 Zob. m.in. Oświadczenie Komisji Episkopatu Polski do Dialogu z Judaizmem na 50. rocznicę wyzwolenia obozu zagłady Auschwitz-Birkenau w Oświęcimiu, Centrum Dialogu i Modlitwy w Oświęcimiu, Oficjalne teksty Episkopatu Polski. www. cdim.pl/pl/edukacja/zasoby-edukacyjne/teksty/52-oficjalne-teksty-kocioa-katolickiego; List pasterski Episkopatu Polski z okazji 25. rocznicy ogłoszenia soborowej deklaracji „Nostra aetate” (30.22.1990), Oświadczenie Rady Episkopatu Polski w sprawie krzyży w Oświęcimiu, (26.08.1998). 
Fałszywie pojmowane i realizowane chrześcijaństwo, zbudowane na powszechnej w starożytnej i późniejszej Europie religijności naturalnej (cała Europa była religijna, gdy pierwsi chrześcijanie napłynęli na jej tereny z ziemi Izraela), zrodziło tzw. teorię substytucji. Według niej lud żydowski ukarany przez Boga Jedynego za bogobójstwo (wydanie na śmierć Jezusa Chrystusa, Syna Boga) został przez Niego odrzucony, przestał być ludem wybranym, a w jego miejsce wybranie stało się udziałem chrześcijan. Religijność tego rodzaju zbudowana na lęku przed Bogiem i ludźmi, czyli przed życiem i śmiercią skutkowała rozmaitymi formami negatywnego stosunku do Żydów, po usuwanie ich z życia społecznego, a nawet biologicznego. Przy takim podejściu można zatem co najwyżej oczekiwać od chrześcijan poprawy ich stosunku do Żydów, aby był on nie tyle lepszy, co raczej mniej zły.

Jednakże twierdzę, że istnieją bardzo konkretne przyczyny, dla których ta wielka Katastrofa, Szoa, zgotowana Żydom przez Niemców, jakże łatwo pozyskanych dla ideologii nazistowskiej’3, jest wielkim dramatem i wyzwaniem właśnie dla chrześcijan. Dlaczego? Czyżby Żydzi byli ludźmi innymi od pozostałych? Czy istnieje jakaś argumentacja dodatkowa, inna niż ta, której użyła wroga Żydom Zofia Kossak-Szczucka, gdy uznała, że jej i innych obowiązkiem jest pomoc Żydom tak samo, jak innym ludziom, gdy są prześladowani i zabijani? Twierdziła ona, że jest to moralny obowiązek chrześcijan, także wobec wrogów, a za takich miała Żydów.

Cóż takiego jest w samym fakcie istnienia ludu żydowskiego i w jego tożsamości, że właśnie chrześcijanie mają szczegól-

3 Pojęcie holokaust powszechnie używane na określenie tego wydarzenia jest skrajnie nieadekwatne ze względu na swą językową treść, a w swej głębi fałszywe. Posługuje się nim niestety zarówno wielu Żydów, jak i wybitne postaci świata chrześcijańskiego. Nawet Stolica Apostolska i wybitni ludzie Kościoła ulegają temu nawykowi. 
ne powody, by przejmować się Szoa? Pomocą w zrozumieniu wyjątkowej relacji łączącej chrześcijan z Żydami może być zdanie św. Pawła z Listu do Rzymian. Ten gorliwy Żyd, który uwierzył w Jezusa Chrystusa jako Mesjasza, pisze do swych braci chrześcijan: „pamiętaj, że nie ty podtrzymujesz korzeń, ale korzeń ciebie" (Rz 11, 18)4. Głębia i nieustająca nowość tych słów dla chrześcijan są rewolucyjne w porównaniu z jakże rozpowszechnionym myśleniem religijnym. Nie mam żadnej wątpliwości, że właśnie dla rozpowszechnionej wśród chrześcijan mentalności religijnej istota fragmentu Pawłowego jest rewelacyjna. Podczas swej historycznej wizyty w synagodze rzymskiej papież mówił: „Religia żydowska nie jest dla naszej religii rzeczywistością zewnętrzną, lecz czymś wewnętrznym. Stosunek do niej jest inny aniżeli do jakiejkolwiek innej religii"

$\mathrm{Na}$ czym polega ta szczególna więź, to pokrewieństwo tak bliskie, że św. Jan Paweł II nazywa Żydów „naszymi starszymi braćmi w wierze”, zaś papież Benedykt XVI „naszymi ojcami w wierze”? Co składa się na te więzi „rodzinne”, które rodzą żal, smutek i łzy w obliczu Szoa jako próby unicestwienia naszej rodziny? W odpowiedzi na to pytanie trzeba przyjrzeć się wspólnemu „kodowi genetycznemu” obu religii, który powoduje, że św. Jan Paweł II mówił o stosunkach z Żydami i judaizmem jako relacji wewnętrznej dla chrześcijaństwa i jego wyznawców ${ }^{6}$. Na ten wspólny grunt przesądzający o rodzinnym charak-

4 Wszystkie cytaty biblijne za: Biblia jerozolimska, wyd. 1, Poznań 2006.

5 Jan Paweł II, Przemówienie w Synagodze Większej, Rzym 13.04.1986. Słowa te papież powtórzył w przemówieniu do do głównych rabinów Izraela podczas swej wizyty tym kraju w jubileuszowym roku 2000, Jerozolima, 20.03.2000.

6 Z tego powodu watykańska Komisja ds. Dialogu z Judaizmem została umieszczona w ramach Papieskiej Rady do Wspierania Jedności Chrześcijan, nie zaś, jak to ma np. miejsce w strukturze polskiej konferencji episkopatu - w obrębie Rady ds. Dialogu Religijnego. Wydźwięk tego faktu jest ogromny, mimo że zdaje się czysto formalno-organizacyjny. Otóż takie usytuowanie Komisji w Watykanie oznacza - moim zdaniem - ni mniej, ni więcej, że jedność chrześcijan, ekumenia, zależy od dogłębnego uświadomienia sobie i przyjęcia jako własne żydowskich korzeni chrześcijaństwa przez wszystkie jego nurty, Kościoły, wyznania. 
terze relacji wiążącej chrześcijan i Żydów składają się następujące elementy:

\section{Wymiar historyczny}

Judaizm i chrześcijaństwo mają charakter historyczny. Przekonania i poglądy religijne Żydów i chrześcijan nie są wytworem filozofów, zbudowane są nie na teoriach i ideach, lecz na konkretnych doświadczeniach własnej historii. Szczególnie istotne są fakty, które mają charakter wyzwalający dla całych społeczności i poszczególnych osób. W nich wyznawcy judaizmu i chrześcijaństwa dostrzegają moc Boga, nawet jeśli sceptycy widzą tu zjawiska i przyczyny naturalne bądź przypadkowe albo też zwyczajnie je podważają. Przekonanie o obecności Boga w tych wydarzeniach nie pojawia się ex nihilo, lecz w procesie zmagania się własnego rozumu z objawieniem, czyli z wydarzeniami, które nie mieszczą się w naturalnej logice człowieka i jego możliwościach.

Określenie obu religii jako monoteistycznych nie jest wystarczające. Bóg, owszem, jest jeden, podobnie jak w islamie, jednak w islamie inna jest wizja Boga. W przeciwieństwie do Pana, Boga Żydów i chrześcijan, Allach jest niedostępny, nie zajmuje się ludzkim losem na ziemi, lecz przebywa jedynie w niebie, gdzie czeka na swych wyznawców z nagrodą. Historia Żydów i chrześcijan stanowi pewne historyczne continuum, do którego islam w tym sensie nie należy. Z żydowskiego doświadczenia i tradycji religijnej wyrasta cała liturgia, sakramenty, obrzędy, modlitwy chrześcijańskie oraz święta. Bardzo istotną cechą świąt żydowskich jest aktualizacja wydarzenia z przeszłości, które jest celebrowane. Mówi się na przykład podczas Paschy: „Bóg wyciągniętym ramieniem wyprowadził nas z niewoli faraona, przeprowadził przez morze i pustynię, dał w posiadanie ziemię obiecaną. Dziś Jego ramię nie skróciło się i każdy z uczestników święta może zostać uwolniony ze swojej niewoli". Także chrześcijańska lektura Słowa jest mar- 
twa bez oglądania w nim własnego życia i odnoszenia obecnych wydarzeń do tych biblijnych.

Główne święta chrześcijańskie nie istnieją bez swych żydowskich poprzedników. Nie ma tu jednak miejsca ani potrzeby, by kwestię tę rozwinąć. Chrześcijanie bardzo często nie znają swego żydowskiego pochodzenia religijnego, są jak ów pan Jourdain, który nie wiedział, że mówi prozą. A przecież, kiedy Kościół cytuje słowa z 11 rozdziału Księgi Izajasza: „wyrośnie różdżka z pnia Jessego" (Iz 11, 1), odwołuje się do Izraela, do domu Dawida, z którego według tego żydowskiego proroka przyjdzie Mesjasz (podobnie czytamy w genealogii Jezusa - Mt 1).

Bóg Abrahama, Izaaka, Jakuba i Jezusa okazuje się bliski człowiekowi, obecny w historii, w konkretnych wydarzeniach, nie czeka dopiero w niebie, lecz działa na korzyść ludzi na ziemi Pojęciem, które judaizm i chrześcijaństwo bardzo mocno akcentują, jest przymierze. W islamie przymierze nie występuje. Bóg zawiera je z najpierw z konkretnym człowiekiem, potem z ludem, który sobie upodobał, wreszcie z całą ludzkością. Co więcej - i tym polega wyjątkowa specyfika wiary Żydów i chrześcijan - Przymierze to Bóg zobowiązuje się jednostronnie realizować i gwarantować. Rola człowieka oznacza jedynie zgodę na udział w nim. Ci, którzy na Przymierze się zgadzają, doświadczają pośród trudności, odstępstw i powrotów jego owoców w konkretach swego życia indywidualnego i zbiorowego. W rezultacie ich wiara i religijność nabierają charakteru „biblijnego” w tym sensie, że wszystkie fakty, także trudne, smutne, postrzegają jako pochodzące z ręki Boga. Dlatego akceptują je jako pożyteczne, ergo dobre dla nich samych ${ }^{8}$.

Religijność wolności czy strachu?

Istota i sens wiary żydowskiej i chrześcijańskiej ma charakter całkowicie odmienny, wręcz odwrotny niż religijność wła-

7 Por. J. Salij, Eseje tomistyczne, Poznań 1988.

8 Kompendium społecznej nauki Kościoła, Kielce 2005, s. 15-19. 
ściwa naturze człowieka. W tej ostatniej inicjatywa wychodzi od człowieka, który widząc, że nie panuje nad rzeczywistością tak, jakby chciał, próbuje pozyskać Boga, czy raczej siłę wyższa, dla swoich planów i potrzeb wynikających z ludzkiej mentalności. Czyni to, składając Mu rozmaite ofiary. U podłoża naturalnej mentalności religijnej tkwi przekonanie o Bogu wrogim bądź kapryśnym w relacjach z ludźmi. Stąd też należy Go nieustannie przekupywać czy, mówiąc językiem współczesnym korumpować. W rezultacie Bóg ma być sługą człowieka, który chce panować nad historią i ją kreować.

U podłoża religijności naturalnej tkwi lęk przed życiem i ludźmi. Bóg jest projekcją ludzkich wyobrażeń, ludzkiej natury, ograniczeń i namiętności. Religia ma pomagać ten lęk znieczulać, oswajać, a gdy to się nie udaje, poganin kieruje się ku innym bożkom-idolom. W konsekwencji, religijność naturalna dzieli świat na sacrum i profanum. W sferze profanum człowiek kieruje się własnymi przekonaniami i wolą, w sferze sacrum sprawuje kult, aby Bóg nie działał przeciwko niemu i mu błogosławił. Gdy w przestrzeni sacrum doznajemy rozczarowania, przechodzimy do profanum, by tam szukać satysfakcji. Naturalnym skutkiem jest hipokryzja, dwulicowość religijna znajdująca wyraz w licznych powiedzeniach, takich jak np. „Bóg sobie, życie sobie”; „Życie ma swoje wymagania”; „Trzeba jakoś żyć". Gdy przychodzi jakiekolwiek cierpienie, rodzi sprzeciw, bunt i złe myśli o Bogu, który prowadzi bieg historii nie tak jak trzeba. Cierpienie nie ma sensu, należy je odrzucać, szukać ciągłej satysfakcji i kompensacji, a skoro życie zawsze jest pełne cierpienia, więc i ono samo traci sens, zwłaszcza że kończy się śmiercią biologiczną.

W religijności i wierze biblijnej inicjatywę zawsze wykazuje Bóg. Człowiek zmagając się z Bogiem, lecz nie uciekając od cierpienia, doświadcza dobrych skutków własnej zgody na tę inicjatywę i w efekcie kieruje ku Bogu błogosławieństwo: błogosławi Go za wszystkie wydarzenia, bowiem na końcu widzi w nich miłość Boga. Staje się zdolny akceptować historię osobistą i zbiorową, z jej trudnościami, ograniczeniami, słabościami i... grze- 
chami. Dlatego Jan Paweł II mógł zaczynać swój pontyfikat słowami „Nie lękajcie się".

A zatem chrześcijaństwo usuwa podział na sacrum i profanum. Cała historia okazuje sięświęta, cierpienie nabiera sensu, śmierć zaś okazuje się tylko przejściem - niełatwym oczywiście - z jednego sposobu życia do drugiego. Nie oznacza to rzecz jasna, że proces ten dokonuje się bez trudu i zmagania, bez wątpliwości, kryzysów wiary i rozpaczy. Każdy człowiek, także Żyd i chrześcijanin, ma pewną naturę cielesną - ojcowie Kościoła nazywają ją "naturą starego człowieka” - która jednak w zetknięciu ze Słowem Boga, nie tylko zawartym w Pismach, ale też przejawiającym się w konkretnych faktach - podlega stopniowej metanoi, przemianie całego sposobu myślenia i życia. W wierze typu biblijnego przychylność Boga jest darmowa, wszystko jest łaską, którą człowiek otrzymuje za darmo, bez żadnych swoich zasług. Stąd św. Paweł pisał o sobie, że jest „płodem poronionym”, zaś św. Katarzyna ze Sieny mówiła o sobie: „Jestem zero plus grzech". Chrześcijanin świadomy swej totalnej słabości nie czuje się przegrany, lecz przeciwnie, doświadcza radości z obecności Boga, który zawsze okazuje się wierny. Jedno ze świąt żydowskich nazywa się Simchat Tora, czyli Radość Pięcioksięgu, radość z faktu, że Bóg jest obecny pośród tego ludu i działa na jego rzecz. Religijny Żyd i chrześcijanin są mocno zakorzenieni w historii, nie ma złudzeń, stoi twardo na nogach, a szukając Boga i nigdy nie będąc pewnym siebie, nieustannie kwestionuje własne poglądy, przekonania i opinie, by móc stale się rozwijać w relacjach z Bogiem i ludźmi.

\section{Sprzeciw wobec bałwanów}

Izrael był zawsze $\mathrm{w}$ historii znakiem antyidolatrycznym, sprzeciwem wobec bożków, bałwanów, których wyznawały okoliczne narody. Istota Izraela streszcza się w pierwszym przykazaniu: Sz'ma Izrael „Słuchaj Izraelu, Pan jest naszym Bogiem - Panem jedynym. Będziesz więc miłował Pana, Boga twojego, z całego swego serca, z całej duszy swojej, ze wszystkich swych 
sił" (Pwt 6, 4-5). Żydzi są nie narodem, lecz ludem, powołanym stopniowo do życia przez Boga w ramach Przymierza. Gdy Izrael buntował się i sprzeniewierzał Bogu, Pan zawsze okazywał się wierny. Izraelici bardzo długo dochodzili do odrzucenia idoli, czerpiąc naukę z rozczarowań, jakie ich wówczas spotykały. Podobnie rzecz się ma z chrześcijanami, którzy gdy chrześcijaństwo ogarnęło również pogan, jak Izrael musieli przejść i nadal przechodzą historyczną drogę ku wierze biblijnej. Poganin ucieka przed własną historią, przed rzeczywistością, alienując się w najrozmaitsze sfery, jak praca, podróże, hobby, seks, telewizja, lektury, rzekoma pobożność, sekty, diety, narkotyki, używki czy po prostu w konsumpcję. Powolne uwalnianie od naturalnego czy wręcz pogańskiego myślenia religijnego oznacza również sprzeciw wobec wszelkiej magii, czarów, przewidywania przyszłości, horoskopów itp. Zanik żydowskich korzeni w kulturze i religii oznacza powrót kultury i postaw pogańskich. Stąd na przykład tak potężne znaczenie magii i wróżbiarstwa we wszystkich kulturach, także w Europie i Polsce. Gdziekolwiek w świecie włączymy telewizor, na wielu kanałach spotkamy wyłącznie tego rodzaju programy. We Włoszech zarejestrowanych jest 300 tysięcy wróżek, wróżbitów, jasnowidzów itp.

Tzw. „zaglądanie Bogu do rękawa” oznacza zastępowanie Go, uzurpację boskiej mocy i władzy. Prorocy Izraela zawsze sprzeciwiali się wszelkim próbom manipulowania, posługiwania się Bogiem, ponieważ rezultatem takich postaw jest na końcu uznanie za Boga to, co Nim nie jest, a zatem fałszywy absolutyzm i fundamentalizm? .

\section{Wymiar antropologiczny}

Judaizm i chrześcijaństwo głoszą specyficzną, tylko im właściwą, wizję człowieka. Nie ma w niej rozdziału między duszą

9 Ks. Józef Tischner mawiał, że fundamentalizm oznacza traktowanie jako fundamentu tego, co fundamentem nie jest. 
a ciałem. W konsekwencji, mogą oni, dzięki mocy Boga, chwalić Go jednym i drugim. Stąd koncepcja osoby ludzkiej, małżeństwa, płciowości, relacji międzyludzkich, więzi wspólnotowych. Najwyższy przedstawia się Żydom jako Bóg żywych, a nie umarłych. Człowiek jako stworzony przez Boga jest do Niego podobny, inaczej niż w religiach pogańskich, gdzie człowiek tworzy sobie boga na własne podobieństwo, antropologizując bóstwo. W judaizmie, podobnie jak później w nauce chrześcijańskiej i Magisterium Kościoła katolickiego, osoba ludzka ze względu na swe pochodzenie ma niezwykłą godność, bez względu na swe cechy, ułomności, słabości, grzechy. Dlatego zawsze ma ona pierwszeństwo przed grupą, społecznością, społeczeństwem czy nawet całym ludem. Jednak zarazem z tego samego powodu - świętości czy, mówiąc inaczej, niezwykłości osoby jako pochodzącej od Boga, który jest Święty i Niezwykły - szczególnego znaczenia nabierają relacje między osobami. Stąd wywodzą się wszelkie instytucje rodzinne, gminne, prawne. Z osobowej godności wywodzi się, co więcej, wszelka odpowiedzialność za życie innych. Więzi wynikające z judeochrześcijańskiej koncepcji osoby nadają szczególne znaczenie ludzkim czynom, które zawsze - dobre czy złe - mają wpływ na sytuację materialną, psychiczną i duchową innych ludzi. Stąd czerpie Kościół swoje zasady życia wspólnotowego. W realizacji tych zasad ważną rolę odgrywa pieniądz jako sposób na przekraczanie granic osobowego egoizmu.

Judaizmowi przypisuje się dokonanie rewolucji seksualnej, która za dobre uznała jedynie relacje między mężczyzną a kobietą. Skoro cechą Boga jest budzenie do życia, to Jego porządek wskazuje na akt seksualny między nimi jako jedynie uprawomocniony, gdyż może on dać nowe życie. Relacja między mężczyzną a kobietą, począwszy od ślubu i wesela, jest przestrzenią liturgiczną, zaś zbliżenie cielesne między nimi dokonuje się jakby na ołtarzu. Całe zewnętrzne otoczenie Izraelitów w swym pogaństwie za normalne uznawało wszelkie inne rodzaje seksu, z homoseksualizmem, zoofilią i prostytucją sakralną włącznie. Ze względu na historyczne doświadczenie Żydów, które uczy, że 
Bóg ze śmierci wyprowadza życie, pojawiła się oblubieńcza wizja Jego relacji do człowieka („Pieśń nad Pieśniami”). Oblubieńczy charakter tego związku legł u podstaw tak wielkiego nacisku położonego w judaizmie na małżeństwo i rodzinę. Rodzina jako minigmina żydowska stała się wzorem dla chrześcijańskiego Kościoła domowego.

Przy okazji warto wspomnieć, jak ważnym elementem kultury żydowskiej jest gościnność czy, mówiąc ogólniej, stosunek do innych: „Przybysza, który się osiedlił wśród was, będziecie uważać za obywatela. Będziesz go miłował jak siebie samego, bo i wy byliście przybyszami w ziemi egipskiej"10. Podobnie cechą charakterystyczną jest wzgląd na ubogich. W ortodoksyjnych rodzinach żydowskich na weselu muszą być obecni żebracy.

Tym, co różni judeochrześcijańską antropologię od innych religii, przede wszystkim zaś od innych, zwłaszcza typowo ludzkich źródeł moralności, jest akceptacja kruchości człowieka, więcej, kruchość ta jest drogą poznania siebie i Boga jako źró$\mathrm{dła}^{11}$. Zgodnie z powszechnym przekonaniem kulturowym człowiek nie może okazać się słaby, nieporadny, grzeszny, wątpiący, zdrajcą... W świecie takiej moralności, powiedzielibyśmy typu harcerskiego, gdzie zdobywa się sprawności i zasługi, staramy się zatem zasłużyć na dobrą opinię i akceptację innych. Naturalnym sposobem jest zakrywanie swych realnych braków i złych czynów, przywdziewanie masek ludzi dobrych, bo w przeciwnym razie okażemy się niegodni odpowiedniego miejsca w społeczeństwie. Sens chrześcijańskiego orędzia zasadzającego się na żydowskiej koncepcji wybrania, której symbolem jest Jakub-Izrael - Bóg wybiera sobie kogo chce, raczej tych słabych, bez orderów - najlepiej wyrażają słowa św. Pawła: „Przechowujemy zaś ten skarb - tzn. moc i chwałę Boga [uwaga moja, J. G.] - w na-

${ }^{10} \operatorname{Kpł} 19,34$.

${ }^{11}$ Zob. J. Grosfeld, Kruchość jako istotny wymiar chrześcijańskiej tożsamości, [w:] red. J. Grosfeld, 50 lat później. Posoborowe dylematy wspótczesnego Kościoła, Warszawa 2014, s. 23-34. 
czyniach glinianych, aby z Boga była owa przeogromna moc, a nie z nas" 12 .

Świadomość własnej kruchości rodzi się z kolejnych doświadczeń, że autorem dobra jest zawsze Bóg, nie człowiek. Ludzkie przekonanie o własnych siłach jest przeciwne. Dlatego Żydzi na pustyni mogli zbierać w danym dniu tylko jedną miarę manny - ewentualne nadwyżki się psuły - by następnego dnia od nowa oczekiwać daru od Boga. Wszystko to prowadzi bowiem do całkiem skandalicznego w ludzkiej mentalności wezwania Jezusa Chrystusa „miłujcie waszych nieprzyjaciół”. Realizacja tej postawy nie leży w możliwościach człowieka, konieczne jest zwrócenie się do Boga, który ma moc i chęć, by nam jej udzielić.

Dobrze jest wiedzieć, że Dekalog nie jest zbiorem nakazów, jak sugerowałoby polskie słowo przykazanie. Dziesięć słów stanowi swoistą obietnicę Boga: jeśli pójdziecie za Mną, te rzeczy spełnią się w waszym życiu.

Wszystkie nakazy Prawa żydowskiego i zasady życia chrześcijańskiego w gruncie rzeczy mają jedno na celu. Powołaniem Żyda i chrześcijanina jest dawać świadectwo o Bogu Jedynym nie tylko najbliższym w rodzinie, nie tylko współobywatelom, ale każdemu człowiekowi. Świadectwo to dotyczy przede wszystkim kwestii dobra i zła, sensu życia, cierpienia i śmierci.

\section{Stosunek do dobra i zła}

Judaizm i chrześcijaństwo mają bardzo klarowną wizję dobra i zła. Jednakże w przeciwieństwie do wielu innych religii, ze świeckimi włącznie, akceptują istnienie zła w świecie. Obie religie są zaprzeczeniem gnostycznego czy manichejskiego myślenia o relacji dobra i zła. Nie chodzi tu, rzecz jasna, o wspieranie zła lub bierność wobec niego, lecz o pozostawienie Bogu sądu, wyroku i jego wykonania. Jest to postawa skandaliczna dla mentalności pogańskiej, wedle której zło należy wyplenić najpierw

122 Kor 4,7 . 
osądem, potem zaś ogniem i mieczem. Tymczasem bez istnienia zła nie wiemy, czym jest dobro. Krzyż Jezusa Chrystusa jest najbardziej gorszącym i budzącym sprzeciw obrazem stosunku chrześcijaństwa do zła. Przebaczenie i miłosierdzie jest sądem Boga nad człowiekiem czyniącym zło, czyli nad każdą istotą ludzką. Postawę tę widać już u Żydów. Dawid nie zgodził się na rozprawienie się z obrzucającym go obelgami Szimei, dworzaninem wrogiego mu Saula, uważając, że być może dzieje się to z woli samego Pana (por. 2 Sm 16, 10). Stałe kwestionowanie własnej sprawiedliwości, uznawanie się za grzesznika jest podstawą, warunkiem spotkania z Bogiem. Dawid czyni tak po grzechu z Batszebą, gdy upomniał go prorok. Woła: „Zgrzeszyłem wobec Pana"13.

Miłosierdzie Boga dla człowieka ma uobecniać się w postawie Żyda, a tym bardziej chrześcijanina wobec winnego. Do tego potrzebne jest nazwanie zła po imieniu, aby było jasne, że jest co przebaczać. Żydowski dobry uczynek, micwa, jest zapowiedzią chrześcijańskiego tzw. uczynku życia wiecznego. Miłość Chrystusa, większa niż śmierć, owocuje w chrześcijaninie otwieraniem nieba drugiemu człowiekowi, który przeciwko niemu zawinił. Kluczem jest tutaj przebaczenie. Żyd także nie pełni własnej sprawiedliwości, odwetu, jakiego domaga się jego serce, ale mierzy wszystko miarą Boga. Te uczynki nigdy nie płyną z natury człowieka, ale są autorstwa Boga samego. Nigdy nie dość przypominać słów Jezusa, który na pytanie o zło odpowiada: pochodzi ono z ludzkiego, czyli z mojego, a nie z twojego wnętrza. Gdy pomijamy światło pochodzące od Boga, wówczas poszukiwanie źródeł zła w świecie, pytanie unde malum?, prowadzi zawsze do szukania źródeł w innych, nie w sobie. Owa projekcja zła na zewnątrz wynika wprost z opisanej wyżej samoobronnej postawy ludzkiej natury, która nie chce wypaść źle w oczach innych. Stąd tak trudno jest znaleźć ludzi, np. w polityce, którzy przyznają się do własnych win, zaniedbań, błędów.

${ }^{13} 2 \operatorname{Sm~11,13.}$ 


\section{Aktualizacja orędzia}

Przetrwanie monoteizmu Żydów poprzez tysiąclecia prześladowań, które miały ich ukarać bądź skłonić do odstępstwa od wiary, jest cudem pośród zalewu mentalności pogańskiej w świecie. Można powiedzieć, że fakt ten jest dowodem na istnienie Boga Abrahama, Izaaka i Jakuba, który w każdym pokoleniu zachowuje, wybiera dla siebie resztę Izraela. Nie dokonuje się to w jakiś magiczny sposób, lecz poprzez Słowo zawarte w Pismach. Mamy tu do czynienia z niezwykle istotnym dla tożsamości żydowskiej i chrześcijańskiej sposobem podejścia do Słowa i historii, a mianowicie z ich nieustanną aktualizacją. Słowo nie jest odnoszone do przeszłości, lecz do teraźniejszości, historia biblijna dzieje się dzisiaj, najpierw przez stawianie pytania: Jak to Słowo odnosi się dzisiaj do mnie? Podczas sederu paschalnego dzieci dzieli się na mądre i głupie. Przed hagadą, czyli opowieścią ojca rodziny o wyprowadzeniu Żydów z niewoli egipskiej, mądre dziecko zadaje pytanie: "Jak to się stało, że wyszliśmy z Egiptu?”, zaś głupie dziecko pyta: „Jak to się stało, że wyszliście z Egiptu?", nie utożsamiając się z Żydami, nie widząc ciągłości historii. Ojciec odpowiada temu ostatniemu: „Ty głupcze, gdybyś był wówczas w Egipcie, to nie wyszedłbyś z tej niewoli”. I dlatego chrześcijanin nie mówi: „Żydzi (albo Rzymianie) zabili Jezusa Chrystusa”, lecz „,ja Go dziś zabiłem”.

Jednym z najistotniejszych, bodaj czy nie najważniejszym zadaniem Żyda i chrześcijanina jest przekazywanie wiary następnym pokoleniom. Dokonuje się to przede wszystkim w rodzinie. I tutaj pierwotnym źródłem jest fragment z Księgi Powtórzonego Prawa: „Niech pozostaną w twym sercu te słowa, które Ja ci dziś nakazuję. Wpoisz je twoim synom, będziesz o nich mówił przebywając $\mathrm{w}$ domu, w czasie podróży, kładąc się spać i wstając ze snu" (Pwt 6, 6-7).

Wychowanie religijne, edukacja dokonuje się u Żydów nie tylko przez naukę i katechizację (niesłychanie rozwinięty system edukacji religijnej), ale także - a może przede wszystkim - przez postawy rodziców, które dzieci otrzymują drogą 
jakby osmozy w życiu codziennym. Najważniejsze jest bowiem przekazywanie obecności Boga w ludzkiej słabości oraz indywidualny i wspólnotowy wymiar życia. Odcinanie się od tych korzeni żydowskich skazuje chrześcijan na uwiąd, albowiem przekaz rodzinny najsilniej kształtuje dziecko na dobre i na złe. Więź międzypokoleniowa polegająca na przekazie doświadczeń ma centralne znaczenie. Podstawą judaizmu i chrześcijaństwa jest nieustannie odnawiana tradycja, która szuka wciąż nowych form i treści, by odpowiadać na nowe zjawiska i procesy, na obecne dylematy ludzi. Problem relacji między świadomością obecnego a doświadczeniem przeszłych pokoleń, czyli między nowoczesnością a tradycją dobrze oddaje obraz liliputa siedzącego na barkach olbrzyma: liliput sam z siebie widzi niewiele, siedząc olbrzymowi na plecach widzi jednak więcej niż on, ma rozleglejszy horyzont i perspektywę.

Diaspora rodząca się w bolesnych okolicznościach rozmaitych form wygnania, opuszczenia odegrała wielką rolę w umacnianiu pamięci żydowskiej, a z drugiej strony w poszerzaniu i wzbogacaniu jej treści. Wydaje się, że najważniejszą rolę odegrała ona w procesie „oddomowienia” ludu żydowskiego, który - jak każdy człowiek - nadmiernie przywiązuje się do tego, co ma, także do świątyni i ziemi ${ }^{14}$. Prześladowania, jakich Żydzi zaznawali i zaznają w świecie, rodzą jednak w sposób naturalny tendencję przeciwną, której sens jest do odkrywania.

\section{Katastrofa i dramat wybrania}

Żydzi bardzo często stawiali sobie w historii pytanie: Czy Bóg idzie pośrodku nas? Obecność Boga nie jest bowiem dla człowieka czymś oczywistym, zwłaszcza w sytuacjach prześladowań, pogromów, jakichkolwiek przeciwności. Zawsze wtedy pojawia się pokusa rozpaczy, zwątpienia, rezygnacji albo też odpowiadania złem na zło, uciekania się do przemocy, realizacji całkowi-

${ }^{14}$ Zob. J. Grosfeld, Żyd wieczny tułacz, „Studia Bobolanum” (2011) nr 2, s. 5-27. 
cie ziemskiej wersji wybrania. Nie bez powodu jednak podczas rytu paschalnego Żydzi brali na ofiarę jagnię z owcy łagodnej, która nie opiera się zadawanej jej przemocy. Ofiara Izaaka, tzw. Akeda, czyli związanie Izaaka, polegała właśnie na wyrzeczeniu się przemocy ze względu na zaufanie do sensu ludzkiej historii, którą prowadzi Bóg. Postawa pokory wobec historii, owocująca przebaczeniem i pojednaniem, stanowi most łączący ludzką naturę i miłość własną z miłością i mocą Boga. Chęć odpowiedzenia przemocą na przemoc płynie z zakwestionowania wierności Boga zawartemu Przymierzu.

Wydarzeniem, które pytanie o wierność Boga i sens historii postawiło w sposób najbardziej radykalny, wręcz skandaliczny, była Szoa, Katastrofa, czyli zagłada Żydów, która w zamyśle Hitlera miała być ostatecznym rozwiązaniem problemu żydowskiego, a w ślad za tym wszelkich problemów człowieka. Zagłada okazała się najpotężniejszym wyzwaniem dla wiary Żydów ${ }^{15}$, a zarazem dla wiary chrześcijan. Dokonała się ona w schrystianizowanej Europie, co pokazało, że mentalność pogańska jest czymś, czego chrzest nie usuwa w sposób automatyczny. Potrzebne jest długotrwałe dojrzewanie chrześcijan do wiary dojrzałej, sięgającej do korzeni żydowskich, tak by faktycznie mogła być oparta na skale - Jezusie Chrystusie, który jest Objawieniem przychodzącym od Żydów. Mentalności pogańskiej nie da się zmienić szybko, bez długofalowej, poważnej pracy edukacyjnej i katechizacji dorosłych. Zarazem nie należy ulegać złudzeniu, że skutki tego wysiłku będą rychłe i widoczne; na pewno nie okażą się też powszechne. Wszędzie tam, gdzie droga zmiany wymaga autentycznego nawrócenia, należy przyjąć postawę pokory i cierpliwości wobec procesów społecznych.

Świadomość, że nauczanie pogardy wobec Żydów i judaizmu w chrześcijańskiej Europie doprowadziło do straszliwej kata-

15 I. Greenberg, Historia, Holokaust i Przymierze, „Znak” (1990) nr 419-420, s. 103-104. Tekst rabina Greenberga jest szczególnie wart polecenia tym, którzy próbują zgłębiać istotę Szoa i jej wpływ na myślenie żydowskie. 
strofy, miała też jeszcze inny wymiar. Otóż, jeśli Bóg - jak mniemano i głoszono - odrzucił Żydów z powodu nieprzyjęcia przez nich Chrystusa (skądinąd nie kto inny, jak właśnie Żydzi, uznali Go za Mesjasza: kim bowiem byli Jego uczniowie?) i przeniósł Przymierze na chrześcijan, to przecież może On również zerwać je z powodu niewierności chrześcijan. Co więcej, ich odpowiedzialność jest o wiele większa, gdyż wiedzą (o ile wiedzą), kogo zdradzają. Skoro jednak Żydzi zawsze twierdzili, że Bóg jest wierny, dochowujący słowa do ostatniego pokolenia, to jakże mógłby anulować Przymierze z nimi? Pytanie brzmi: czy może ono realizować się poprzez tak straszliwe wydarzenie, jak Zagłada? W Zagładzie i potem została zachowana pewna „reszta” Izraela, choć straumatyzowana, wielokrotnie wykorzeniona i rozproszona. Chrześcijanie natomiast zostali niejako przymuszeni przez historię do zapoczątkowania radykalnej zmiany swego nastawienia i oficjalnego nauczania o Żydach. Zmiana ta widoczna jest w dokumentach Vaticanum Secundum, późniejszych dokumentach Kościołów, a także w oświadczeniach krajowych episkopatów Kościoła katolickiego (Francja, Niemcy, USA, Włochy, Austria, Polska), które prosiły Boga i Żydów o przebaczenie za czyny dokonane przez chrześcijan, wreszcie w tekstach liturgicznych. Jeszcze stosunkowo niedawno katolicki rytuał Wielkiego Piątku zawierał modlitwę „za perfidnych Żydów", a i obecnie w polskim przekładzie Mszału rzymskiego widnieje - sprzeczne z oficjalnym Magisterium Kościoła - sformułowanie o Żydach, którzy niegdyś byli narodem wybranym. Rzecz to zdumiewająca, bowiem oficjalny przekład tekstu Mszału rzymskiego używa precyzyjnego określenia: „Populus priori aquisitionis": lud, który jako pierwszy został nabyty na własność Boga. Nikt nie wykonał większej pracy na polu owej zmiany, niż Jan Paweł II. Jego następcy nie tylko kontynuują tę linię refleksji, lecz z racji swego profilu formacyjnego i intelektualnego (Benedykt XVI) oraz duszpastersko-ludzkiego (Franciszek) pogłębiają ją. Mocnymi przejawami tej postawy były modlitwa Benedykta XVI w Auschwitz czy życie, spotkania i wypowiedzi papieża Franciszka. 
Dotykamy tu kwestii wybrania, zasadniczej dla tożsamości żydowskiej, a także chrześcijańskiej. Fałszywe, pogańskie pojmowanie pojęcia „wybranie” stało się jakże istotnym powodem wrogości chrześcijan do Żydów, a także dalszych rozłamów już w obrębie samego chrześcijaństwa oraz rozmaitych innych postaw nienawiści, pogardy i płynących stąd konfliktów i wojen o zabarwieniu religijnym. Wybranie dokonane przez Boga jest nie tylko nieodwołalne (skoro Bóg, jak głoszono w tzw. teorii substytucji ludu wybranego, gdzie chrześcijanie zastąpili niewiernych Żydów, zmienił swoje nastawienie do Żydów, to może zmieni je i do chrześcijan, skoro ci są jakże często niewierni), ale On dokonuje go nie za zasługi albo z powodu lepszych kwalifikacji wybranego, lecz dlatego, by ujawniła się Jego istota. Polega zaś ona na miłości do człowieka słabego, grzesznika, a nie do człowieka pełnego cnót i zalet, który łatwo mógłby to zasługi przypisać sobie.

Logicznie biorąc, może nasunąć się pytanie, że skoro Bóg miałby odrzucić Żydów za niewierność Bogu i rzekome bogobójstwo, to czy tym bardziej nie odrzuci chrześcijan, skoro Kościół mówi wyraźnie, że to my zabijamy Chrystusa w drugim człowieku, gdy grzeszymy, ponieważ każdy mój grzech dotyka, niszczy i zabija innych ludzi. Skoro zaś nie ma chrześcijanina, który by tu na ziemi całkowicie wyzbył się skażonej natury, to każdy chrześcijanin grzeszy i wszyscy byliby odrzuceni.

$$
* * *
$$

Jest czymś paradoksalnym, że relacje chrześcijańsko-żydowskie były w historii i wielokrotnie nadal są naznaczone potężnym piętnem niechęci, wrogości, a nawet nienawiści, ujawniającej się przy rozmaitych okazjach, jak to obserwujemy w wielu krajach europejskich, a także na innych kontynentach. Problem jest tym większy, że podłoże wrogości do Żydów ma charakter religijny, religia zaś bardzo często stanowi dla człowieka i grup społecznych ostateczną pieczęć pod wyrokiem skazującym „innego" z powodów politycznych, społecznych czy kulturowych. 
Wspólna specyfika religijna chrześcijaństwa i judaizmu ${ }^{16}$ powinna, teoretycznie rzecz biorąc, oddziaływać w przeciwnym kierunku. Nieodzowne jest wciąż powtarzać fakt zdawałoby się oczywisty, że odcięcie korzeni - żydowskich - musi oznaczać usychanie całej rośliny: chrześcijaństwa, ale i ludzkości w ogóle. Pomocne może tu być zdanie, jakie usłyszałem kiedyś od pewnego zmarłego niedawno zakonnika: „W chrześcijaństwie nie istnieje pojęcie «tragedii», lecz mamy do czynienia $\mathrm{z}$ «dramatem»". Dla chrześcijanina żadna sytuacja ziemska nie jest ostateczna, nie może zatem kończyć się rozpaczą. Tyle że posługiwanie się tą prawdą wobec drugiego, który cierpi, zwłaszcza wobec Żyda, który do dziś nosi w swym sercu przebieg i skutki Szoa, jest nieznośnym moralizmem, który dzieli i zabija. Dlatego trzeba najpierw zrozumieć, a co najważniejsze opłakiwać żydowski ból i cierpienie, dla których nie można arbitralnie ustalić daty końcowej. Jest wielu chrześcijan i innych, którzy mówią: "Już dość, Żydzi, wystarczająco rozpaczaliście nad tym, co was spotkało, a niektórzy z was uprawiają w dodatku «religię holokaustu», czerpiąc z niej zyski”. Zarzuty te, choć w niektórych przypadkach mogą znajdować potwierdzenie, co może zdarzyć się każdemu człowiekowi, formułowane są przez ludzi, którzy nigdy nie współczuli Żydom, nigdy nie traktowali tego straszliwego wydarzenia jako kataklizmu ogólnoludzkiego, a tym bardziej żydowskiego, i stosują nieznośny moralizm wobec ofiar i ich potomków. Postawę te dobrze odzwierciedla znana opowieść żydowska, w której słynny chasydzki rabin wyznaje, jak wiele nauczył się o współczuciu i głębi słów z Księgi Powtórzonego Prawa $(19,8)$ dzięki zasłyszanej rozmowie dwóch pijanych:

- Iwan, czy ty mnie kochasz?

- Oczywiście, że cię kocham.

- Czy wiesz, co mnie boli?

${ }^{16}$ Kościół katolicki o swoich korzeniach, praca zbiorowa, Polska Rada Chrześcijan i Żydów, Warszawa 1995; D. Flusser, Chrześcijaństwo religia żydowska, Warszawa 2003. 
- Jakże mogę wiedzieć, co cię boli, Borys?

- Iwan, jeśli nie wiesz, co mnie boli, to jak możesz mnie kochać?

\section{Zaciemnienie orędzia Jezusa Chrystusa}

Istotnym czynnikiem rodzącym te współczesne nam postawy wobec Żydów jest zniekształcona postać wiary, a raczej religii chrześcijańskiej. Wielokrotnie w historii obraz chrześcijańskiego orędzia był dla świata niejasny z powodu takich czy innych postaw Kościoła i ludzi ochrzczonych. Zafałszowanie religii chrześcijańskiej, upodobnienie jej do religijności pogańskiej, zbudowanej na lęku przed Bogiem i ludźmi, z nieprawdziwą wizją Boga i człowieka, było i jest silnie obecne w historii i teraźniejszości chrześcijaństwa. Hitler i nazizm stanowili przejaw najwyższego rozwoju owego pogaństwa, które wdarło się do chrześcijaństwa podczas ewangelizacji religijnej przecież Europy. Chrześcijaństwo zaakceptowało ówczesny stan mentalności europejskiej, zaszczepiając się na niej, lecz rzecz jasna, nie likwidując jej. Historia potoczyła się w taki sposób, że ochrzczony naród europejski, jakim byli Niemcy, naród o wielkich dokonaniach kulturowych, był w stanie urodzić i realizować koncepcję człowieka tak dalece obcą chrześcijaństwu (człowiek mocny zamiast człowieka kruchego, zaś Bóg jako idol, którym się posługujemy).

Teza, że religia, także religia chrześcijańska, w swych rozmaitych postaciach była i jest współcześnie wykorzystywana instrumentalnie dla osiągania celów politycznych i społecznych, choć banalna, rodzi jednak nowe pytania. Dotyczą one nie tylko prognoz odnośnie do przyszłości religii, ale również przyczyn, dla których instrumentalizacja chrześcijaństwa, czy jak kto woli, tzw. wartości chrześcijańskich, staje się w ogóle możliwa. Zjawisko to obserwujemy bowiem nie tylko w łonie islamu czy religii pogańskich, ale także w różnych konfesjach chrześcijańskich. Ma ono miejsce zarówno na gruncie europejskim czy amerykańskim, jak i w krajach afrykańskich, azjatyckich czy latynoamerykańskich. W sferze politycznej mamy tu do czynie- 
nia z dwoma podstawowymi typami instrumentalizacji. Pierwszy z nich realizuje prawicowa strona sceny politycznej i intelektualnej poprzez swoisty melanż idei konserwatywnych bądź narodowych z chrześcijaństwem. Postawa ta niezwykle mocno uwydatnia znaczenie rodziny, tradycji, narodu, patriotyzmu, przede wszystkim zaś prawa, które miałoby skutecznie promować i egzekwować określone postawy. Akcent ten jest tak daleko idący, że Bóg i Jego obecność schodzi na plan dalszy, ustępując miejsca wartościom, które pozbawione swego źródła, stają się wartościami moralnymi czy prawnymi, tracąc tym samym życie. Dokonuje się swoista ideologizacja religii.

Drugi rodzaj instrumentalizacji właściwy jest pewnym nurtom lewicowym, które dążąc do zmiany struktur społeczno-politycznych, wykorzystują zakorzenione w konkretnych społeczeństwach przekonania i autorytety religijne, a w szczególności elementy społecznego nauczania Kościoła. Po tej stronie światopoglądowej widoczne jest także świadome posługiwanie się fałszywym lub ułomnym obrazem religii w celu jej ogólnej kompromitacji.

Oba rodzaje instrumentalizacji traktują ewangelię, Biblię, tradycję chrześcijańską i Magisterium Kościoła w sposób wybiórczy, mając na celu nie zbawienie ludzi, do którego prowadzić ma Kościół, lecz takie urządzenie życia społecznego, które odpowiadałoby światopoglądowi bądź poglądom autorów instrumentalizacji (stąd wojny religijne!). Dokonują oni przy tym szczególnego wyboru elementów nauki chrześcijańskiej, przykrawając ją do swojej miary. Skutkiem takiego stosunku do religii, do chrześcijaństwa jest czynienie zeń zbioru wartości społecznych, kulturowych, spychające doświadczenie wiary na dalsze miejsce. Wówczas nadaje się prawu najwyższą moc i rangę drogi i, co gorsza, źródła zbawienia, podczas gdy obecność żywego Boga, Jego łaska i miłosierdzie traci swe centralne i rewolucyjne dla ludzkiego życia znaczenie ${ }^{17}$.

17 Por. T. Halík, Europejskie mówienie o Bogu i milczenie o Bogu, Poznań 2005; J.-M. Garrigues, Demokracja progresistowska albo polityczny integryzm, "Znak" (1998) nr 514, s. 34-43. 
Liczne przykłady instrumentalizacji religii, wynikającej również nierzadko z nieświadomości lub fałszywego uformowania mentalności religijnej, spotykamy w przestrzeni życia publicznego w Europie; nie brakuje ich w Polsce (choćby słynny spór o krzyże na oświęcimskim Żwirowisku). Często mamy również do czynienia z pewnym pomieszaniem uczciwych intencji z próbami politycznego wykorzystania konkretnej sytuacji dla własnych celów politycznych. W każdym razie jest to potężne wyzwanie dla Kościoła i chrześcijan, jakim jest zakres i sposób obecności religii w życiu publicznym.

$$
* * *
$$

Powyższe zniekształcenia $\mathrm{w}$ prezentacji i percepcji religii chrześcijańskiej nie charakteryzują jedynie polityków czy ideowych kreatorów zbiorowego myślenia, lecz są właściwe większości ludzi, a głębiej rzecz ujmując, każdemu człowiekowi ze względu na jego naturę. I tutaj dotykamy drugiej sfery, w której ma miejsce instrumentalizacja religii - życia osobistego czy, inaczej mówiąc, jednostkowych postaw i związanych z nimi poglądów religijnych. Występujące w tej przestrzeni przykrawanie chrześcijańskiego orędzia do własnych wyobrażeń czy korzyści ma swe źródło z jednej strony w konsumpcyjnym traktowaniu religii, stosownie do własnych potrzeb, z drugiej zaś z braków, zaniedbań czy wręcz fałszywych prezentacji np. Magisterium Kościoła katolickiego. Intencje i cele Soboru Watykańskiego II, a także uprzedniego nauczania były wielokrotnie i są nadal zniekształcane bądź ukazywane w sposób niezrozumiały. Nie tylko Kościół katolicki, lecz i inne Kościoły chrześcijańskie, a co dopiero powiedzieć o podstawowych nurtach islamu, bardzo często mają trudności z wydobyciem głębokich treści z korpusu swej doktryny czy nauki w sposób adekwatny do problemów ludzi współczesnego nam świata ${ }^{18}$. Te dwa zjawiska, związane z potężnymi prze-

${ }^{18}$ J. Ratzinger, Sól ziemi. Chrześcijaństwo i Kościót na przełomie tysiącleci, Kraków 1997, s. 147-154. 
mianami cywilizacyjnymi XX i XXI wieku, z traumatycznymi doświadczeniami totalitaryzmów i wojen światowych powodują, że większość społeczeństw niegdyś religijnej, ochrzczonej Europy znajduje się dziś w stanie praktycznego odstępstwa nie tylko od Kościoła i religii, ale przede wszystkim od wiary.

Nie jest celem niniejszego tekstu narzekanie na stan mentalności religijnej chrześcijan, choćby w Polsce, lecz ukazanie najbardziej istotnych cech chrześcijaństwa, które wywodząc się z religijnych korzeni żydowskich, stanowią o jego wyjątkowej specyfice. Albowiem wobec opisanych wyżej tendencji kulturowych, sekularyzacji i zaniku sensus religiosus, a wreszcie wobec naturalnych skłonności ludzkiej natury do stawiania w centrum własnego, źle pojmowanego ego, należy zadać pytanie: Co robić? Odpowiedź moim zdaniem brzmi: ukazywać wciąż na nowo właściwy sens chrześcijaństwa, a w ślad za tym wyjaśniać pojęcia i idee oraz ich źródła, które w przeważającej mierze tkwią w religijnym doświadczeniu Żydów jako ludu wybranego przez Boga Jedynego. Potężna nowość, jaką jest Dobra Nowina o Jezusie Chrystusie, nie daje się sprowadzić oczywiście do prostej kontynuacji czy adaptacji Przymierza zawartego z historycznym Izraelem. Zarazem jeszcze mocniej idzie ona w kierunku sprzeciwiającym się instrumentalizacji religii przez człowieka. Można nawet powiedzieć, że w obrębie tradycji żydowskiej orędzie chrześcijańskie stanowi pewną rewolucję, której mocne przeczucie znajdujemy u Izajasza i Ezechiela. Misja Jezusa Chrystusa bowiem z istoty swej wytrąca naturalne ludzkie myślenie religijne, a ostatecznie ma usuwać jego ograniczenia, ukazując pełniej oblicze Boga jako miłującego grzesznego człowieka w sposób niczym nieuwarunkowany. Świadomości tego rewolucyjnego wymiaru chrześcijaństwa nie nabywa się natychmiast ani w sposób naturalny. Można nawet zaryzykować tezę, że Kościół powszechny przeżywa niezwykle długi okres dojrzewania, dorastania do głębi i pełni wiary w paschalną tajemnicę Chrystusa, idąc drogą błędów, grzechów indywidualnych i społecznych, na podobieństwo drogi, którą lud Izraela szedł do Ziemi Obiecanej, czyli do ściślejszej więzi z Bogiem. 


\section{Konieczność nieustannego powrotu do źródeł}

Doświadczanie przez chrześcijan własnego życia w wymiarze wiary oraz płynące stąd zrozumienie głębi ciągłości Pierwszego i Drugiego Testamentu oraz ich przełożenia na historię ludzką: społeczną, polityczną, kulturową, musi w sposób naturalny rodzić wdzięczność dla Boga nie tylko za stworzenie człowieka i troskę o niego, ale też za istnienie Żydów, w których Bóg sobie szczególnie upodobał, których wybrał z Jemu tylko wiadomego powodu. Bez Żydów nie byłoby Żyda Jezusa Chrystusa, chrześcijaństwa, nie byłoby tej niezwykłej i jakże głęboko prawdziwej wizji człowieczeństwa, którą tak pięknie ukazują Psalmy. Podobnie i obraz Żydów prowadzonych jak owce na śmierć przez nazistów, śpiewających modlitwy zawarte właśnie w Psalmach nie może nie poruszać serca.

Szczególnie niebanalną prawdą, dopiero odkrywaną przez chrześcijan na nieco większą skalę, jest związek między trwaniem, a co więcej, rozwojem duchowym chrześcijaństwa, a istnieniem i trwaniem Żydów. Zresztą istnieje tu także wzajemny związek między rozwojem duchowym wyznawców judaizmu i chrześcijaństwa. Judaizm i wyznający go Żydzi są niezbędni aż do końca dziejów, by historia zbawienia mogła się w pełni zrealizować. Skoro korzeń podtrzymuje drzewo, a dzika oliwka zaszczepiona na oliwce prawdziwej nie przetrwa bez niej, to chrześcijaństwo bez Żydów i judaizmu jest jedynie spoganiałą, fałszywą mutacją tego, co dla chrześcijan jest najpiękniejsze: bezwarunkowej miłości Boga do człowieka i rodzącej się z niej miłości człowieka do człowieka.

Szoa stanowiła nie tylko próbę usunięcia Żydów z ziemi, ale też zlikwidowania tej wizji człowieka i Boga, jaka została im zaszczepiona i jaką bardziej czy mniej wiernie nieśli przez tysiąclecia. Tym samym była to próba zniszczenia podstawy chrześcijaństwa, ponieważ bez korzenia drzewo więdnie i usycha, gdyż nie ma skąd czerpać soków dla nieustającej odnowy i przemiany mentalności. Krzewienie tej świadomości jest niezwykle ważnym zadaniem Kościoła, którego misją jest szerzenie auten- 
tycznej i integralnej wiary chrześcijańskiej, nie zaś jej heretyckich mutacji, często zakorzenionych w rozmaitych nurtach filozofii europejskiej i innej, oraz troska o żywotność przekazu. Droga do jedności chrześcijan wiedzie przez jedność z innymi ludźmi, ta zaś zawsze przez zgodę na ukrzyżowanie swojego rozumu, serca, całości dyspozycji wewnętrznej. 